\title{
Liver and brain metabolism alterations in patients with minimal hepatic encephalopathy
}

\author{
Zmiany metabolizmu wątroby i mózgu u pacjentów z minimalną encefalopatią \\ wątrobową
}

Irena Maria Ciećko-Michalska1', Tomasz Dziedzic², Agnieszka Słowik², Tomasz Hubert Mach², Robert Paweł Banyś Mirosława Orłowiejska², Marek Binder ${ }^{4}$, Mirosław Wyczesany ${ }^{4}$

1Department of Gastroenterology, Hepatology and Infectious Diseases, Jagiellonian University Medical College, Krakow, Poland 2Department of Neurology, Jagiellonian University Medical College, Krakow, Poland

${ }^{3}$ Center for Diagnostic, Prevention and Telemedicine, John Paul II Hospital, Krakow, Poland

4Psychophysiology Laboratory, Institute of Psychology, Jagiellonian University, Krakow, Poland

Prz Gastroenterol 2013; 8 (2): 115-119

DOI: $10.5114 /$ pg.2013.33213

Key words: minimal hepatic encephalopathy, proton magnetic resonance spectroscopy, Wechsler Adult Intelligence Scale. Słowa kluczowe: minimalna encefalopatia wątrobowa, protonowa spektroskopia rezonansu magnetycznego, Skala Inteligencji Wechslera.

Address for correspondence: Irena Maria Ciećko-Michalska MD, Department of Gastroenterology, Hepatology and Infectious Diseases, Jagiellonian University Medical College, 5 Sniadeckich St, 31-531 Krakow, Poland, phone: +48 124247382 , fax: +48 12 424 73 82, e-mail: michalska@su.krakow.pl

\begin{abstract}
Introduction: Minimal hepatic encephalopathy (MHE) is a neuropsychiatric complication of chronic liver disease, predominantly liver cirrhosis. Due to the lack of clear clinical symptoms, early diagnosis of MHE is difficult and relies mainly on neuropsychological tests.

Aim: We studied the correlations between cognitive impairment as measured by a Polish adaptation of the Wechsler Adult Intelligence Scale (WAIS-R (PL)) and selected biochemical parameters such as prothrombin time (PT), ammonia concentration and brain metabolites detected by proton magnetic resonance spectroscopy ( $\mathrm{H}^{1} \mathrm{MRS}$ ) in patients with liver cirrhosis and controls.

Material and methods: Material and methods: Localized proton magnetic resonance spectroscopy was performed in $36 \mathrm{pa}$ tients with chronic liver disease and 34 healthy volunteers matched for age, gender and level of education. In each participant laboratory and neuropsychological tests was performed.

Results: The examined blood parameters of liver function were similar in patients with and without MHE and were significantly abnormal compared to the control group. Only in patients with MHE did PT and ammonia concentration correlate with total WAIS-R (PL), verbal subscore of WAIS-R (PL) and non-verbal subscore of WAIS-R (PL). Cirrhotic patients showed a significant reduction of myo-inositol/creatine $(\mathrm{Mi} / \mathrm{Cr})$ and myo-inositol/choline (Mi/Cho) ratios in the three studied brain regions as compared to controls. Patients with MHE "+" had
\end{abstract}

\section{Streszczenie}

Wstęp: Minimalna encefalopatia wątrobowa (minimal hepatic encephalopathy - MHE) jest neuropsychiatrycznym powikłaniem przewlekłych chorób wątroby, szczególnie marskości. Ze względu na brak wyraźnych objawów klinicznych rozpoznanie MHE jest trudne i opiera się głównie na testach neuropsychologicznych.

Cel: Badanie korelacji między zaburzeniami funkcji poznawczych mierzonymi za pomocą polskiej adaptacji Skali Inteligencji Wechslera (WAIS-R (PL)) a wybranymi parametrami biochemicznymi krwi, takimi jak czas protrombiny (prothrombin time - PT), stężenie amoniaku, oraz stężeniem metabolitów mózgu identyfikowanych za pomocą protonowej spektroskopii rezonansu magnetycznego (proton magnetic resonance spectroscopy - H1MRS) u pacjentów z MHE lub bez w porównaniu z grupą kontrolną.

Materiat i metody: Badanie protonowej spektroskopii rezonansu magnetycznego przeprowadzono u 36 pacjentów z przewlekłą chorobą wątroby i u 34 zdrowych ochotników odpowiednio dobranych pod względem wieku, płci i poziomu wykształcenia. U każdego uczestnika wykonano badania laboratoryjne oraz testy neuropsychologiczne.

Wyniki: Wyniki badań biochemicznych oceniających czynność wątroby były podobne $u$ chorych na MHE i bez niej, jednak różniły się istotnie $\mathrm{w}$ porównaniu z grupą kontrolną. Tylko u pacjentów z MHE PT i stężenia amoniaku korelowały z wynikami testów WAIS-R (PL), zarówno werbalnych, jak i niewerbalnych. U pacjentów z marskością wątroby stwierdzono 
significantly decreased ratio of $\mathrm{NAA} / \mathrm{Cr}$ as compared to the MHE "-" group in gray matter in the posterior occipital cortex. Conclusions: Our study shows some brain metabolic disturbances typical only for MHE. The $H^{1}$ MRS can be helpful in the diagnosis of this disease.

\section{Introduction}

Minimal hepatic encephalopathy (MHE) is a common neuropsychiatric disorder in patients with chronic liver diseases without any neurological signs and symptoms during a bedside examination [1, 2]. In previously published studies the diagnosis of MHE was usually based on the results of different simple psychometric tests, such as trail making test $A$ and $B$, block design test, digit symbol test and others [3-6]. This approach seems to be responsible for the wide range of prevalence of MHE in different studies, from 35\% to 84\% [7]. It could also be responsible for the lack of data on biological markers of MHE. The Wechsler Adult Intelligence Scale (WAIS-R) is a commonly accepted method used to assess the premorbid cognitive abilities [8]. Significant impairment in cognitive functions, especially in the nonverbal domain of this test, allows one to differentiate patients with and without cognitive dysfunctions. In patients with liver cirrhosis the WAIS-R has been tested only by a few authors $[9,10]$. The studies showed that patients with liver cirrhosis performed much worse on the nonverbal part of this test than the controls. The WAIS-R test has not previously been applied to differentiate patients with chronic liver diseases with and without MHE.

\section{Aim}

We studied the correlations between cognitive impairment as measured by a Polish adaptation of WAIS-R (WAIS-R (PL)) [11] and the blood markers of liver function, and brain metabolites detected by proton magnetic resonance spectroscopy ( $\left.\mathrm{H}^{1} \mathrm{MRS}\right)$ in patients with liver cirrhosis and controls.

\section{Material and methods}

We included 36 patients with chronic liver disease, i.e., alcoholic liver cirrhosis, primary biliary cirrhosis and hemochromatosis, selected in the outpatient clinic of the Department of Gastroenterology Hepatology and Infectious Diseases, Jagiellonian University, Krakow, Poland.

Patients were diagnosed based on laboratory tests, ultrasound examination or computed tomography of the znaczące zmniejszenie stosunku myo-inositol/creatine (Mi/CR) i myo-inositol/choline (Mi/Cho) w trzech badanych regionach mózgu w porównaniu z grupą kontrolną. Pacjenci z MHE "+" mieli znacząco zmniejszony stosunek $N$-acetyloasparginianu/kreatyny (NAA/Cr) w porównaniu z grupą MHE “-” w substancji szarej kory mózgu w płacie potylicznym.

Wnioski: W badaniu wykazano zmiany stężeń metabolitów mózgu typowych tylko dla MHE. Protonowa spektroskopia rezonansu magnetycznego może być pomocna w rozpoznawaniu tej jednostki chorobowej.

abdominal cavity, and in some cases by liver biopsy with histopathological examination. Thirty-four healthy volunteers matched for age, gender and level of education, selected among the staff of the University Hospital and families of the patients, served as controls. The local Ethical Committee approved the study.

Each person participating in the study signed an inform consent form prior to the study.

In each patient and all subjects of the control group the WAIS-R $(\mathrm{PL})$ test was performed. Minimal hepatic encephalopathy (MHE “+") was diagnosed in cirrhotic patients without any neurological signs and symptoms whose WAIS-R (PL) test showed significant deficits of premorbid cognitive abilities. Significant impairment was defined as a difference between verbal and nonverbal score of WAIS-R (PL) higher than 16 points (mean + one standard deviation in the controls).

At the time of neuropsychological testing the following blood markers of liver function were studied using standard laboratory techniques: alanine aminotransferase (ALT), aspartate aminotransferase (AST), albumin, bilirubin, prothrombin time (PT) and ammonia concentration. The metabolic abnormalities in the brains of all study participants were measured. Proton magnetic resonance spectroscopy ( $\left.\mathrm{H}^{1} \mathrm{MRS}\right)$ imaging was performed on the 1.5 Magnetom Vision Plus (Siemens Erlangen, Germany). Three voxels of $8 \mathrm{~cm}^{3}$ were positioned in: 1) predominantly white matter in the posteromedial parietal cortex, 2) predominantly gray matter in the posterior occipital cortex, 3) globus pallidus. The following ratios were assessed: myo-inositol/creatine $(\mathrm{Mi} / \mathrm{Cr})$, choline/creatine (Cho/Cr), $\mathrm{N}$-acetyl aspartate/creatine (NAA/Cr), myo-inositol/choline (Mi/Cho), N-acetylaspartate/choline (NAA/Cho).

\section{Statistical analysis}

Data on quantitative characteristics are expressed as means \pm standard deviation (SD). Data on qualitative characteristics are expressed as percentage values or absolute numbers as indicated. Comparisons between groups were made with the $\chi^{2}$ test (nominal data) or Student's $t$-test (interval data). A value of $p$ below 0.05 was considered statistically significant. 
Table I. Demographic data, blood markers of liver dysfunction and brain metabolite concentrations in patients with MHE, without MHE and in the control group

Tabela I. Dane demograficzne, parametry biochemiczne czynności wątroby oraz metabolity mózgu u pacjentów z MHE, bez MHE i z grupy kontrolnej

\begin{tabular}{|c|c|c|c|c|}
\hline Parameter & MHE “+” $[\mathrm{A}]$ & MHE “-” [B] & Controls [C] & Value of $p$ \\
\hline Age, mean \pm SD [years] & $51.7 \pm 10.7$ & $47.2 \pm 12.0$ & $47.3 \pm 10.4$ & $\begin{array}{l}\text { A vs. } B=N S \\
\text { A vs. } C=N S \\
B \text { vs. } C=N S\end{array}$ \\
\hline Sex, $n(\%)$ (females) & $7(46.7)$ & $7(33.3)$ & $15(44.1)$ & $\begin{array}{l}\text { A vs. } B=N S \\
\text { A vs. } C=N S \\
B \text { vs. } C=N S\end{array}$ \\
\hline $\begin{array}{l}\text { Education, } n(\%) \\
\text { (at least } 12 \text { years) }\end{array}$ & $13(59.9)$ & $8(53.3)$ & $18(54.6)$ & $\begin{array}{l}\text { A vs. } B=N S \\
\text { A vs. } C=N S \\
B \text { vs. } C=N S\end{array}$ \\
\hline Albumin $[g / l]$ & $36.6 \pm 7.2$ & $38.2 \pm 6.4$ & $43.3 \pm 6.1$ & $\begin{array}{c}\text { A vs. } B=N S \\
\text { A vs. } C=0.004 \\
B \text { vs. } C=0.009\end{array}$ \\
\hline $\mathrm{ALT}[\mathrm{U} / \mathrm{I}]$ & $58.5 \pm 48.9$ & $66.4 \pm 51.4$ & $28.6 \pm 10.8$ & $\begin{array}{c}\text { A vs. } B=N S \\
\text { A vs. } C=0.008 \\
B \text { vs. } C=0.001\end{array}$ \\
\hline $\mathrm{AST}[\mathrm{U} / \mathrm{I}]$ & $62.8 \pm 47.3$ & $65.4 \pm 47.3$ & $24.6 \pm 10.8$ & $\begin{array}{l}\text { A vs. } B=N S \\
\text { A vs. } C=0.0003 \\
\text { B vs. } C=0.0001\end{array}$ \\
\hline Bilirubin $[\mu \mathrm{mol} / \mathrm{l}]$ & $20.6 \pm 17.4$ & $37.2 \pm 75.5$ & $11.1 \pm 5.5$ & $\begin{array}{l}\text { A vs. } B=N S \\
\text { A vs. } C=0.01 \\
B \text { vs. } C=0.08\end{array}$ \\
\hline PT & $1.3 \pm 0.4$ & $1.2 \pm 0.2$ & $1.0 \pm 0.1$ & $\begin{array}{c}\text { A vs. } B=N S \\
\text { A vs. } C=0.002 \\
\text { B vs. } C=0.02\end{array}$ \\
\hline Ammonia $[\mu \mathrm{mol} / \mathrm{l}]$ & $62.1 \pm 58.2$ & $55.7 \pm 21.5$ & $31.6 \pm 17.0$ & $\begin{array}{c}\text { A vs. } B=N S \\
\text { A vs. } C=0.02 \\
\text { B vs. } C=0.0001\end{array}$ \\
\hline \multicolumn{5}{|c|}{ Predominantly white matter in the posteromedial parietal cortex } \\
\hline $\mathrm{Mi} / \mathrm{Cr}$ & $0.111 \pm 0.036$ & $0.123 \pm 0.044$ & $0.291 \pm 0.109$ & $\begin{array}{l}\text { A vs. } B=N S \\
\text { A vs. } C=0.0000001 \\
\text { B vs. } C=0.0000001\end{array}$ \\
\hline $\mathrm{Ch} / \mathrm{Cr}$ & $0.924 \pm 0.396$ & $0.998 \pm 0.341$ & $0.850 \pm 0.229$ & $\begin{array}{l}\text { A vs. } B=N S \\
\text { A vs. } C=N S \\
B \text { vs. } C=N S\end{array}$ \\
\hline $\mathrm{NAA} / \mathrm{Cr}$ & $1.414 \pm 0.589$ & $1.594 \pm 0.619$ & $1.479 \pm 0.464$ & $\begin{array}{l}\text { A vs. } B=N S \\
\text { A vs. } C=N S \\
B \text { vs. } C=N S\end{array}$ \\
\hline Mi/Cho & $0.129 \pm 0.052$ & $0.138 \pm 0.068$ & $0.361 \pm 0.145$ & $\begin{array}{c}\text { A vs. } B=N S \\
\text { A vs. } C=0.000002 \\
B \text { vs. } C=0.0000001\end{array}$ \\
\hline NAA/Cho & $1.566 \pm 0.479$ & $1.635 \pm 0.478$ & $1.808 \pm 0.630$ & $\begin{array}{l}\text { A vs. } B=N S \\
\text { A vs. } C=N S \\
B \text { vs. } C=N S\end{array}$ \\
\hline \multicolumn{5}{|c|}{ Predominantly gray matter in the posterior occipital cortex } \\
\hline $\mathrm{Mi} / \mathrm{Cr}$ & $0.106 \pm 0.031$ & $0.136 \pm 0.052$ & $0.303 \pm 0.111$ & $\begin{array}{c}\text { A vs. } B=N S \\
\text { A vs. } C=0.000002 \\
\text { B vs. } C=000001\end{array}$ \\
\hline $\mathrm{Ch} / \mathrm{Cr}$ & $0.869 \pm 0.242$ & $0.979 \pm 0.240$ & $0.945 \pm 0.190$ & $\begin{array}{l}\text { A vs. } B=N S \\
\text { A vs. } C=N S \\
B \text { vs. } C=N S\end{array}$ \\
\hline
\end{tabular}


Table I. Cont.

Tabela I. Cd.

\begin{tabular}{|c|c|c|c|c|}
\hline Parameter & MHE “+” [A] & MHE “-” [B] & Controls [C] & Value of $p$ \\
\hline $\mathrm{NAA} / \mathrm{Cr}$ & $1.276 \pm 0.405$ & $1.687 \pm 0.475$ & $1.626 \pm 0.648$ & $\begin{array}{c}\text { A vs. } B=0.02 \\
\text { A vs. } C=N S \\
B \text { vs. } C=N S\end{array}$ \\
\hline $\mathrm{Mi} /$ Cho & $0.129 \pm 0.042$ & $0.151 \pm 0.087$ & $0.399 \pm 0.162$ & $\begin{array}{c}\text { A vs. } B=N S \\
\text { A vs. } C=0.0002 \\
\text { B vs. } C=0.00009\end{array}$ \\
\hline NAA/Cho & $1.558 \pm 0.712$ & $1.737 \pm 0.333$ & $1.726 \pm 0.593$ & $\begin{array}{l}\text { A vs. } B=N S \\
\text { A vs. } C=N S \\
B \text { vs. } C=N S\end{array}$ \\
\hline \multicolumn{5}{|c|}{ Globus pallidus } \\
\hline $\mathrm{Mi} / \mathrm{Cr}$ & $0.116 \pm 0.032$ & $0.116 \pm 0.037$ & $0.295 \pm 0.097$ & $\begin{array}{c}\text { A vs. } B=\text { NS } \\
\text { A vs. } C=0.0002 \\
\text { B vs. } C=0.00002\end{array}$ \\
\hline $\mathrm{Ch} / \mathrm{Cr}$ & $0.890 \pm 0.266$ & $0.860 \pm 0.184$ & $0.961 \pm 0.353$ & $\begin{array}{l}\text { A vs. } B=N S \\
\text { A vs. } C=N S \\
B \text { vs. } C=N S\end{array}$ \\
\hline $\mathrm{NAA} / \mathrm{Cr}$ & $1.427 \pm 0.660$ & $1.356 \pm 0.302$ & $1.600 \pm 0.540$ & $\begin{array}{l}\text { A vs. } B=N S \\
\text { A vs. } C=N S \\
B \text { vs. } C=N S\end{array}$ \\
\hline $\mathrm{Mi} /$ Cho & $0.140 \pm 0.059$ & $0.138 \pm 0.047$ & $0.340 \pm 0.148$ & $\begin{array}{c}\text { A vs. } B=N S \\
\text { A vs. } C=0.003 \\
\text { B vs. } C=0.0005\end{array}$ \\
\hline NAA/Cho & $1.597 \pm 0.771$ & $1.590 \pm 0.214$ & $1.759 \pm 0.673$ & $\begin{array}{l}\text { A vs. } B=N S \\
\text { A vs. } C=N S \\
B \text { vs. } C=N S\end{array}$ \\
\hline
\end{tabular}

\section{Results}

Minimal hepatic encephalopathy was diagnosed in 15 out of 36 patients with liver cirrhosis (41.7\%). The studied blood parameters of liver function were similar in patients with and without MHE and were significantly abnormal as compared to controls (Table I).

Only in patients with MHE "+" did PT and ammonia concentration correlate significantly with the WAIS-R (PL) total score (PT vs. WAIS-R (PL) total: $r=-0.72, p<0.05$ and ammonia concentration vs. WAIS-R $(\mathrm{PL})$ total: $r=-0.72, p<0.05)$.

In this group of patients PT and ammonia concentration also correlated both with verbal subscore of WAIS-R (PL) (PT vs. verbal subscore of WAIS-R (PL): $r=-0.68$, $p<0.05$ and ammonia concentration vs. verbal subscore of WAIS (PL): $r=-0.67, p<0.05)$ and non-verbal subscore of WAIS-R (PL): (PT vs. non-verbal subscore of WAIS-R (PL): $r=-0.71, p<0.05$ and ammonia concentration vs. non-verbal subscore of WAIS-R (PL): $r=-0.72$, $p<0.05)$.

MHE "+" and MHE "-" groups showed a significant reduction of $\mathrm{Mi} / \mathrm{Cr}$ and $\mathrm{Mi} / \mathrm{Cho}$ ratios in the three studied brain regions as compared to controls. The MHE "+" group had a significantly decreased ratio of $\mathrm{NAA} / \mathrm{Cr}$ compared to the MHE "-" group in gray matter in the posterior occipital cortex (Table I).

\section{Discussion}

This study shows that $41.7 \%$ of patients with chronic liver disease suffer from a significant deficit of premorbid cognitive abilities assessed by means of WAIS-R (PL). Our approach to diagnosing MHE, although time consuming (the session of neuropsychological testing lasted about $2 \mathrm{~h}$ ) allowed us to study in detail cognitive functions in this group of patients. We were also able to find some brain metabolic disturbances typical only for MHE "+", but not for cognitively intact cirrhotic patients (MHE "-"). Patients with MHE "+" compared to MHE "-" show a lower NAA/Cr ratio in gray matter in the posterior occipital cortex, suggesting greater neuronal dysfunction in the first group [10]. What is more, only MHE “+” patients presented with significant correlations between cognitive deficit and some blood markers of liver dysfunction.

Our study confirmed previous data showing a decrease of $\mathrm{Mi} / \mathrm{Cr}$ and $\mathrm{Mi} / \mathrm{Cho}$ ratios in patients with liver 
cirrhosis as compared to controls [12-17]. In astrocytes myo-inositol acts as an organic osmolyte, and is released from the cells in response to osmotic cell swelling [18]. Interestingly, in our study this decrease was found not only in cirrhotic patients with a premorbid spectrum of cognitive deficits but also in cirrhotic patients with normal WAIS-R (PL) test results.

In our study only patients with MHE "+" show significant correlations between blood ammonia concentration or PT and WAIS-R (PL) score. Such correlations were not found in MHE "-" patients and in controls. This indicates that ammonia concentration and PT could be good markers of cognitive impairment, but only in patients with MHE "+".

According to neuropathological examinations, hepatic encephalopathy is related mainly to the changes in morphology and function of glial cells, which might suggest that it is a primary gliopathy [19]. Neuron degeneration and dysfunction is a process occurring later, secondary to the astrocytes lesion. Correlations between blood markers of liver function and the results of psychometric tests in patients with MHE have been found previously only by a few authors. For example, Tarter et al. reported the correlation between PT or albumin levels and the results of psychometric tests in nonalcoholic cirrhotic patients. They did not, however, differentiate patients with and without MHE [20].

\section{Conclusions}

Our study shows that patients with liver cirrhosis present with a decreased ratio of $\mathrm{Mi} / \mathrm{Cr}$ and $\mathrm{Mi} / \mathrm{Cho}$ as compared to controls. Patients with liver cirrhosis and minimal hepatic encephalopathy have a decreased $\mathrm{NAA} / \mathrm{Cr}$ ratio as compared to cirrhotic patients with normal cognitive abilities. $\mathrm{H}^{1} \mathrm{MRS}$ can be helpful in diagnosis of MHE.

\section{Acknowledgments}

The study was supported by a grant from the Minister of Science and Higher Education (N N404 153134).

\section{References}

1. Ortiz M, Jacas C, Cordoba J. Minimal hepatic encephalopathy: diagnosis, clinical significance and recommendations. J Hepatol 2005; 42: 45-53.

2. Stewart CA, Smith GE. Minimal hepatic encephalopathy. Nat Clin Pract Gastroenterol Hepatol 2007; 4: 677-85.

3. Zeegen R, Drinkwater JE, Dawson AM. Method for measuring cerebral dysfunction in patients with liver disease. $\mathrm{Br}$ Med J 1970; 2: 633-6.

4. Amodio P, Del Piccolo F, Marchetti P, et al. Clinical features and survival of cirrhotic patients with subclinical hepatic alterations detected by a number connection test and computerized psychometric tests. Hepatology 1999; 29: 1662-7.
5. Gilberstadt SJ, Gilberstadt H, Zieve L, et al. Psychomotor performance defects in cirrhotic patients without overt encephalopathy. Arch Intern Med 1980; 140: 519-21.

6. Kulisevsky J, Pujol J, Deus J, et al. Persistence of MRI hyperintensity of the globus pallidus in cirrhotic patients: a 2-year follow-up study. Neurology 1995; 45: 995-7.

7. Gitlin N. Sublinical portal systemic encephalopathy. Am J Gastroenterol 1988; 83: 8-11.

8. Ricker JH (ed). Differential diagnosis in adult neuropsychological assessment. Springer Publishing Company. Inc NY 2004.

9. Sood GK, Sarin SK, Mahaptra J, et al. Comparative efficacy of psychometric tests in detection of subclinical hepatic encephalopathy in nonalcoholic cirrhotics: search for rational approach. Am J Gastroenterol 1989; 84: 156-9.

10. Rikkers L, Jenko P, Rudman D, et al. Subclinical hepatic encephalopathy: detection, prevalence, and relationship to nitrogen metabolism. Gastroenterology 1978; 75: 462-9.

11. Brzeziński J, Gaul M, Hornowska E, et al. Wechsler Adult Intelligence Scale. Revised version WAIS-R(PL). Handbook [Polish]. Laboratory of Psychological Tests of the Polish Psychological Association, Warsaw 2004.

12. Geissler A, Lock G, Fründ R, et al. Cerebral abnormalities in patients with cirrhosis detected by proton magnetic resonance spectroscopy and magnetic resonance imaging. Hepatology 1997; 25: 48-54.

13. Laubenberger J, Häussinger D, Bayer S, et al. Proton magnetic resonance spectroscopy of the brain in symptomatic and asymptomatic patients with liver cirrhosis. Gastroenterology 1997; 112: 1610-6.

14. Binesh N, Huda A, Bugbee $M$, et al. Adding another spectral dimension to $1 \mathrm{H}$ magnetic resonance spectroscopy of hepatic encephalopathy. J Magn Reson Imaging 2005; 21: 398-405.

15. Singhal A, Nagarajan R, Hinkin CH, et al. Two-dimensional MR spectroscopy of minimal hepatic encephalopathy and neuropsychological correlates in vivo. J Magn Reson Imaging 2010; 32: 35-43.

16. Rovira A, Grivé E, Pedraza S, et al. Magnetization transfer ratio values and proton MR spectroscopy of normal-appearing cerebral white matter in patients with liver cirrhosis. AJNR Am J Neuroradiol 2001; 22: 1137-42.

17. Weissenborn K, Ahl B, Fischer-Wasels D, et al. Correlations between magnetic resonance spectroscopy alterations and cerebral ammonia and glucose metabolism in cirrhotic patients with and without hepatic encephalopathy. Gut 2007; 56: 1736-42.

18. Thomas MA, Huda A, Guze B, et al. Cerebral $1 \mathrm{H}$ MR spectroscopy and neuropsycholo gical status of patients with hepatic encephalopathy. AJR Am J Roentgenol 1998; 171: 1123-30.

19. Butterworth RF. Hepatic encephalopathy: a central neuroinflammatory disorder? Hepatology 2011; 53: 1372-6.

20. Tarter RE, Sandford SL, Hays AL, et al. Hepatic injury correlates with neuropsychologic impairment. Intern J Neurosci 1989; 44: $75-82$. 